\title{
The Epistemology of Religious Diversity in Contemporary Philosophy of Religion
}

\author{
A M I R D A T M A L C H I A N \\ Foundation for Interreligious and Intercultural Research and Dialogue \\ and University of Geneva
}

\begin{abstract}
This is the draft version of: Dastmalchian, A. (2013), 'The Epistemology of Religious Diversity in Contemporary Philosophy of Religion' in Philosophy Compass, vol. 8, issue 3, pages 298-308. $<$ http://onlinelibrary.wiley.com/doi/10.1111/phc3.12007/abstract> $<$ http://philosophy-compass.com/sections/philosophy-of-religion>
\end{abstract}

The published version appears with two supplements, a teaching and learning guide, and a video abstract.

\section{ABSTRACT}

Religious diversity is a key topic in contemporary philosophy of religion. One way religious diversity has been of interest to philosophers is in the epistemological questions it gives rise to. In other words, religious diversity has been seen to pose a challenge for religious belief. In this study four approaches to dealing with this challenge are discussed. These approaches correspond to four well-known philosophers of religion, namely, Richard Swinburne, Alvin Plantinga, William Alston, and John Hick. The study is concluded by suggesting four factors which shape one's response to the challenge religious diversity poses to religious belief.

\section{INTRODUCTION}

'Religious diversity' is the term used to refer to the existence of a multitude of religious traditions. Religious diversity is now one of the major subjects of the philosophy of religion with most recent introductory textbooks either covering the topic in detail or apologising for its absence. What has emerged from the literature on this topic can be split into first-order reflections on religious diversity and second-order reflections on religious diversity.

First-order reflections on religious diversity are those which consider matters directly arising from the phenomenon of religious diversity. These matters include (a) the epistemology of religious beliefs, (b) concepts of the Ultimate, and (c) the possibility of salvation/liberation across religious traditions (see Byrne).

Second-order reflections on religious diversity are those which seek to categorise first-order reflections and which seek to find the most appropriate strategy for approaching the phenomenon of religious diversity. Second-order reflections have produced the 'tripolar typology' (Schmidt-Leukel) of exclusivism, inclusivism, and pluralism; a typology which originated with Race. These three key labels combine with a variety of adjectives to give rise to a very specific terminology for discussing the phenomenon of religious diversity. The most common adjectives used are 'epistemic', and 'salvific' (or 'soteriological') but other adjectives might include 'experiential', 'alethic', 'doctrinal', 'normative', 'deontological', 'ethical', and 
so forth (King, Legenhausen). For example, then, epistemic exclusivism (with regard to religious diversity) would be the position that only one particular religion is epistemically advantaged to the exclusion of all the other religions and epistemic pluralism would be the position that more than one religion is epistemically advantaged.

In this study I will be focussing on first-order epistemological reflection on religious diversity (mentioned as (a) above). I will do this by introducing the work of four contemporary and recent philosophers of religion who have made a significant contribution to the subject through defending the reasonableness (rationality) of religious belief. These philosophers are Richard Swinburne (1934-), Alvin Plantinga (1934-), William Alston (1921-2009), and John Hick (1922-2012). I will conclude the study by drawing attention to themes which run through the work of these philosophers by suggesting four factors which determine how a reflective person with religious beliefs might deal with religious diversity on an intellectual level. But

first a few words on why this specific issue is worth discussing at all.

Reflecting on the fact of religious diversity can make a person with religious convictions lose confidence in his religious convictions, or in any religious beliefs whatsoever. This confidence problem is exacerbated by the desire for certainty regarding matters of such primary importance as religious matters. After all, religious traditions can be quite demanding regarding commitment, both practical and cognitive. The person who becomes aware of religious diversity might wonder whether he is correct about religious matters given that most people disagree with him. He asks himself: 'Can everybody apart from my coreligionists and I be wrong about religious matters?' This question is all the more pertinent when he realises that his coreligionists consist of, for example, a reformist trend within a sect within a major religious tradition - not more than a handful of the human population! Another question that a person aware of religious diversity may pose to himself is: 'If there is so much disagreement regarding religious beliefs, how do I know my religious beliefs are true?'

\section{RICHARD SWINBURNE: EVIDENCE, ARGUMENT, AND REASON}

Richard Swinburne is best known for using his academic career to argue for both the epistemic virtues of theism (The Coherence of Theism, The Existence of God, Faith and Reason) and the plausibility of the Christian doctrines which follow from theism (Revelation, The Christian God, Providence and the Problem of Evil, Responsibility and Atonement). ${ }^{1}$ His arguments are summarised in two books written for a non-specialist audience (Was Jesus God? and Is There a God?). At the end of a conference address Swinburne reflected on his work in the philosophy of religion:

Whether or not you accept my claim that the Christian revelation is probably the true one, I hope you will agree that in the ways which I have outlined, reason can weigh the probable truth of rival religions, help us to face up to any inadequacies of our own tradition and any merits of others, and generally help us to overcome the irrational forces which are so hard at work in human religious disputes. (Swinburne 'Christianity and the Discourse' 20) 
Defence of the exclusive correctness of a particular religious tradition through philosophical argument is a well-established practice and often the first type of response a person makes when they feel intellectually threatened by religious diversity. A study of Swinburne's work in the philosophy of religion shows that Swinburne believes (a) Christianity is true, (b) the way to show that any religion is true is with positive arguments, and (c) given a positive argument for Christianity rival religions demand less detailed attention. With regard to (c) Swinburne explains why he does not feel the need to investigate in detail religions rival to Christianity:

I do not need to make a detailed investigation if I can show that none of those religions even claim for themselves characteristics to be expected a priori of a true religion and claimed by Christianity, and that there is enough evidence that Christianity does have these characteristics. For then I will be in a position to argue that there are reasons adequate to show that the Christian religion is more likely to be true than they are. (Swinburne 'Response to My Commentators' 310-311)

So, it can be seen that Swinburne has a priori expectations of what the true religion is like and he finds that these expectations are fulfilled by Christianity alone. An example includes his expectation that God would want to authenticate his revelation with an inimitable signature. The reported resurrection of Jesus of Nazareth, says Swinburne ('Intellectual Autobiography' 15, Resurrection v, Revelation 162, 218), matches our expectations: it was an event which violated the laws of nature and was closely associated with a religious message.

Swinburne's approach to religious enquiry (and consequently to religious diversity) arises from the view that a religious belief should ideally be the result of adequate investigation and objectively correct inductive criteria (Faith and Reason 102). ${ }^{2}$ Adequacy of investigation refers to a person expending sufficient time and effort - that is, giving due diligence - in order to obtain true beliefs (or at least probably true beliefs). Inductive criteria refer to the criteria by which one assesses a belief; for Swinburne these are predictive power, coherence, simplicity, and scope, all of which follow from Swinburne's commitment to bayesian epistemology (Faith and Reason 45, 94). ${ }^{3}$ That these four criteria are objectively correct, according to Swinburne, means that they are conducive to selecting true beliefs.

\section{See Supplement 1}

\section{ALVIN PLANTINGA: BYPASSING THE NEED FOR EVIDENCE}

Alvin Plantinga also defends Christianity. His defence has both negative and positive aspects. The negative aspect is the thorough critique of Western epistemology. The positive aspect is the presentation of an epistemological framework which, he claims, is consistent with Christian teachings on how a person can come to accept Christianity. Here we focus on the positive aspect of Plantinga's Christian apologetic although the two aspects are not easily divorced from each other. ${ }^{4}$

Plantinga says that for a true belief to count as knowledge a person must not only be deontologically justified in believing it (that is, they must not have 
failed any intellectual duties) but they must also be 'warranted'. According to Plantinga (Warranted Christian Belief 153), a belief is warranted if it is produced by a properly functioning cognitive faculty where the proper functioning is determined by a design plan successfully aimed at truth. A warranted belief loses its warrant if it is defeated (that is, successfully challenged) by any secondary considerations.

This account of the 'central core' (Warranted Christian Belief 156) of warrant requires some further elaboration. Firstly, for a cognitive faculty to be properly functioning is for it to be neither impeded nor subject to disorder and dysfunction. Secondly, proper function goes together with the notion of 'design plan' such that for a faculty to function properly it must function according to its design plan (Warranted Christian Belief 154). For example, it is part of the design plan of cognitive faculties that they do not operate effectively under the influence of various drugs such as alcohol and cannabis. It is also part of the design plan of cognitive faculties that they do operate effectively when well rested. The notion of design plan does not have to presuppose a conscious design or purpose. ${ }^{5}$ The reason Plantinga stipulates that a design plan involved in producing warranted belief must be aimed at truth is that sometimes a belief is produced for other reasons (such as for protection - as with a mother who refuses to believe her child is a tearaway so that she does not fall into despair). Also, even if a design plan is aimed at truth it would not be of much use from the point of view of knowledge unless it was successfully aimed at truth, that is, reliable.

Plantinga (Warranted Christian Belief 172) describes how theistic belief can have warrant by appealing to a component called the 'sensus divinitatis'. ${ }^{6}$ This is an innate disposition which helps a person to know God. For example, if a person is in trouble he will call out to God; as Plantinga (Warranted Christian Belief 174) notes 'there are no atheists in foxholes'! Similarly, if a person does a terrible thing he will feel that God disapproves, or if a person beholds the splendour of nature he will feel compelled to praise God. Plantinga terms his description of how the sensus divinitatis operates as the 'Aquinas/Calvin model'. ${ }^{7}$ This model is extended in order to describe how belief in specifically Christian doctrines can be warranted by appeal to another component called the 'Internal Instigation of the Holy Spirit'.

The sensus divinitatis is something we are all born with (Warranted Christian Belief 172-173). The natural knowledge of God it produces is not arrived at by inference or argument, rather knowledge of God is presented to the subject in an immediate way, as with the deliverances of memory and a priori reasoning. In other words, the belief produced by the sensus divinitatis is basic. It is also, says Plantinga, probably warranted to such a degree that it will often be sufficient for knowledge (Warranted Christian Belief 179).

There is a major obstacle to the smooth functioning of the sensus divinitatis. This obstacle is sin. According to Plantinga, sin has cognitive consequences and may cause the sensus divinitatis to become diseased or disabled. If it wasn't for sin the existence of God would be as obvious as the reality of other minds, of the past, and of the external world (Warranted Christian Belief 214). Because mankind has fallen into sin there is a need for rescue and redemption, this is done by the Holy Spirit (Warranted Christian Belief 202, 205). The Holy Spirit, says Plantinga (Warranted Christian Belief 80), instigates faith in the 'great things of the Gospel' in those in whom it acts. This is so that they may be aware of, and so they may potentially attain, the salvation which God has prepared for them (Warranted Christian Belief 243, 250). The Holy Spirit works through scripture so that when a person encounters scripture they form Christian beliefs that are as certain as any 
perceptual beliefs or memory beliefs. Again, these are beliefs which are reasoned from and not reasoned to (Warranted Christian Belief 257, 264, 450).

So, in a nutshell, Plantinga maintains that belief in God and in the central teachings of Christianity are beliefs which can quite rightly be foundational (not inferred from any other belief) for a person or, in his own words, 'properly basic'. Plantinga concludes that Christian beliefs can be considered to be true to the exclusion of other religious beliefs without the need of evidence or argument. This defence of Christianity has become to be known as the 'basic belief apologetic'. Plantinga (Warranted Christian Belief 168-170) claims four things for his models. Firstly, the two models are plausibly true: they show that it is possible (and not just in a strictly logical sense) for theistic and Christian belief to have warrant. Secondly, there are no cogent objections to the claim that the models are true which are not also general objections to theistic or Christian belief. Thirdly, the models are in fact true or close to the truth. Fourthly, the models belong to a range of models which describe the warrant Christian belief can enjoy.

\section{WILLIAM ALSTON: A DOXASTIC PRACTICE APPROACH}

William Alston's opinion on religious diversity is located in the context of him dealing with a challenge to his mystical perception thesis. Alston, in Perceiving God, argues that mystical perception (what others might call mystical experience) can give rise to reliable beliefs, that is, beliefs which are more often true than not. The major challenge to Alston, by his own admission (Perceiving God 7, 239, 255), in arguing for his mystical perception thesis is that there are numerous incompatible forms of mystical perception. The mystics of various religious traditions and even mystics within religious traditions differ in the beliefs they form from their mystical perceptions. Wouldn't such disagreement suggest that mystical perception is an altogether unreliable source of beliefs?

To see how Alston gets himself into this problem we should say a little bit about doxastic practices. A doxastic practice is a belief forming practice with various psychological and sociological features that makes abandoning it extremely difficult, if not impossible, for one who is disposed to using it (Perceiving God 150). Our major doxastic practices include sense perception, introspection, memory, rational intuition, and various types of reasoning (Perceiving God 176). On the basis of some type of stimulus a doxastic practice produces a belief. With the sensory perceptual doxastic practice (SP), for example, we can say that the input is a physical stimulus and the output would be a belief about the physical environment. According to Alston it is prima facie reasonable to engage in the use of socially established doxastic practices because if a doxastic practice is widely used by all types of people it can be plausibly assumed to have epistemic merit. Such doxastic practices can reasonably be expected to produce reliably true beliefs provided there are no reasons to believe the contrary. Alston also mentions the importance of 'significant self-support' in the justification of a doxastic practice: a type of support which is epistemically circular. An example is the necessity of memory for conducting our affairs, but this is only because we remember past occasions where it has helped us. For instance, I remember that bread is nutritious but this is only because I can remember always having eaten bread with no adverse effects!

Alston's mystical perception thesis is that the various practices of forming beliefs from mystical perceptions (each practice corresponding to its own religious 
tradition) are socially established doxastic practices with significant self-support (Perceiving God 184-185). In accordance with the doxastic practice approach it follows that engaging in these mystical perceptual doxastic practices (MPs for short) is prima facie reasonable and their belief outputs can reasonably be supposed to be reliable. But given that there are many incompatible MPs it would seem implausible to say that they are all as valid as each other when it comes to reliably forming true beliefs. So, either (a) only one MP is reliable or (b) no MPs are reliable. In the first case a proof would be needed for the reliability of, say, the Christian-MP and the relative unreliability of all the other MPs. In the second case Alston's claim that the doxastic practice approach applies to MPs would be undermined.

In response to this conundrum Alston (Perceiving God 270, 'Response to Hick' 288) embarks on a 'worst case scenario' thought experiment which supposes that there are no non-circular reasons for distinguishing one MP from the others. But although he rejects (a) he does not accept (b). Instead he insists, by appealing to a number of examples and analogies, that it is reasonable for a religious believer to believe in the reliability of his MP-produced religious beliefs even if they are not supported with positive non-circular reasons. Alston does admit that without noncircular support the reasonableness of believing in the exclusive reliability of one's own MP-produced religious beliefs is 'significantly weakened' but that the reduction is not enough to make these beliefs unreasonable or irrational.

Alston's result can be generalised to apply to a diversity of religious beliefs rather than just a diversity of MP-produced religious beliefs. So, according to Alston (Perceiving God 272), if we cannot even think of an appropriate non-circular proof for the reliability of a particular set of religious beliefs then there is no reason why we should take the absence of such a proof to nullify the reasonableness of supposing the religious beliefs to be reliable. Without a common ground to resolve epistemic conflict then epistemic conflict is less damaging to the reasonableness of religious belief. If there is no way to solve the challenge of religious diversity then the reasonable thing for a religious believer to do is to continue to believe in the reliability of his religious beliefs and not to abandon them. As Alston (Perceiving God 275) says, 'incompatible propositions can each be justified for different people if what they have to go on is suitably different.'

\section{JOHN HICK: SIMILAR APPROACH, DIFFERENT SOLUTION}

John Hick meets the epistemological challenge of religious diversity in a similar way to Alston, namely through defending the reasonableness of basing religious beliefs on religious experience. According to Hick for a person to undergo religious experiences is for the person to make a choice about the way he interprets the ambiguous universe that surrounds him. As with Alston, Hick does not aim to show that religious experiences are veridical but rather that it is reasonable for those who have them to suppose that they are veridical. Hick points out that we have to rely on our sensory experiences even though we cannot logically prove them to be veridical. There is no logical proof, suggests Hick (An Interpretation 213, 214), of an external world yet it is reasonable to believe in our perceptual experiences. Similarly, we have to rely on our religious experiences even though we cannot prove them to be veridical.

Alston believes that, due to religious diversity, forming beliefs on the basis of religious experiences would be unreasonable were it not for the significant self- 
support that mystical doxastic practices have. Hick also believes that religious diversity would initially seem to have a negative impact on the reasonableness of a person trusting his religious experiences. It is not feasible, says Hick ( $A n$ Interpretation 234), to believe that all the various gods of the various religions exist. However, unlike Alston, Hick does not appeal to significant self-support in order to keep his ideas about religious experience rationally respectable. Instead Hick argues that the differing religious experiences are all ultimately compatible with each other. According to Hick, the assumption that only one religion can be true must be abandoned, especially given that a number of religious traditions seem as epistemically well based as each other (Hick 'The Epistemological Challenge of Religious Pluralism' 278-279).

The consequence of Alston's position is that a person who undergoes religious experiences can disregard the religious experiences of individuals of rival religious traditions. This applies to the situation where there are no good reasons to prefer one religious tradition over others (which Alston calls the 'worst case scenario'). This is completely unsatisfactory for Hick ('The Epistemological Challenge of Religious Pluralism' 278, An Interpretation 235) who maintains that it would be arbitrary to hold one's own religious experiences as reasonable to the exception of all others in the absence of good reasons.

Hick takes inspiration from Immanuel Kant's (1724-1804) distinction between the noumenon (reality as it is in itself) and the phenomenon (reality as it is perceived by a subject). Hick supposes that each of the great religious traditions of the world is based on an attempt to understand the noumenon but each great religious tradition only manages to construct a partially adequate understanding of the noumenon in its own cultural terms. In fact Hick replaces reference to the 'noumenon' with reference to the 'Real as it is in itself'. The Real is Hick's preferred term for what might also be termed the 'Ultimate', the 'One', or 'Ultimate Reality', and so forth. The equivalent of phenomenal reality in Hick's hypothesis is the Real as variously understood by different religious traditions rather than as it actually is. As Hick envisages it, the Real is utterly transcendent. Other than strictly logical properties (such as 'being able to be referred to') we cannot make any literal ascriptions to the Real. The narratives of various religious traditions, therefore, about their various ultimates are only metaphorically true.

\section{See Supplement 2}

\section{CONCLUSION}

So far we have seen how four notable philosophers of religion defend the reasonableness of religious belief and how they have responded to the challenge that religious diversity poses to religious belief. We saw how both Swinburne and Plantinga defend belief in one particular religion (that is, Christianity) to the exclusion of any other religion. While Alston also maintains this stance he shows more recognition of how precarious it is. Hick, on the other hand, finds a way to reconcile religious beliefs with religious diversity by denying the assumption that only one religion must be true.

The differences between our four philosophers can be traced to differences on the following matters: 
1. Epistemic obligations

2. Religious ambiguity

3. Epistemic parity

4. Religious incompatibility

In closing this study I will explain these four factors in turn and relate them to the four philosophers discussed.

Firstly, differing views of epistemic obligations are most clearly seen in the differing approaches of Swinburne and Plantinga to establishing similar positions (what was called epistemic exclusivism at the beginning of this study). While Swinburne is committed to basing Christian beliefs on evidence Plantinga is more concerned to show that evidence is not necessary for a Christian given that faith can be inculcated in a different way. The former position has been termed as 'evidentialism' while the latter position, arising from the Reformed epistemology movement, ${ }^{8}$ resembles a range of positions which give prominence to faith in matters of religious belief and which are known as 'fideism'.

Evidentialism fits well with epistemic internalism which is the view that for a person to be justified in his beliefs he must be internally aware that he has met his epistemic obligations, whatever they may be. This view has been denied by 'externalists' who have wanted to say that a person need not be aware that they are justified just so long as they are. One way this position has been articulated is through arguing that a belief can be justified if it is produced by a reliable process, even if a person is not aware about the process.

Secondly, while Swinburne and Plantinga differ on the obligation to base beliefs on evidence, neither of them affirms that the world we experience is ambiguous such that we might have particular difficulty in making sense of its religious dimension. Even if they recognise some ambiguity in the world they would say that the world can be disambiguated. Alston does recognise religious ambiguity in the world, albeit only by way of thought experiment. For this reason he does not insist on the challenge of religious diversity being resolved through disambiguation and in favour of a definite outcome. Instead Alston is content to advocate that a person is entitled to stick with the beliefs he has. Hick, who actually does believe that the religious dimension of the world is ambiguous, is not content with Alston's position. Hick can be said to be insisting on the obligation of belief assessment in the light of a strong challenge to existing beliefs. In other words, if a person faces certain information (such as the fact of religious diversity) he must seek to accommodate the information by adjusting his existing beliefs so that they are consistent with the information. It is not appropriate, maintains Hick, for a person to respond to the challenge with dogmatism.

While the first two factors shape one's epistemological approach to maintaining the rationality of religious belief in the light of religious diversity they do not ultimately determine whether one religion is upheld as offering an exclusively correct account of religious matters or not. Whether one chooses to attest to the truth of one religion or of multiple religions will depend on the third and fourth factors. So, thirdly, if a person believes that the doctrines of only one religious tradition have epistemic merit then they surely will want to maintain that one religion is exclusively true. This is clearly the position of Swinburne and Plantinga. On the other hand, if a person believes that different religious worldviews corresponding to different religions are all equal in epistemic merit then 
they will probably want to deny that any one religion has a monopoly on truth. This is the position of Hick.

Fourthly, if a person believes that the worldviews of the different religious traditions are incompatible with each other then he will deny that more than one of them can be true. Putting aside incompatibilities in religious practice, it would seem that different religious worldviews give rise to propositions which contradict each other, for example, that there is one God, that there is more than one God, or that there is no God at all. Hick argues that the different religious worldviews are incompatible if taken literally but not if taken metaphorically. After all, we would not think that Shakespeare's metaphor that all the world is a stage ${ }^{10}$ is incompatible with his metaphor that the world is an oyster. ${ }^{11}$ Similarly, if different religions are understood to espouse metaphorical worldviews then they need not be incompatible with each other. Neither Swinburne, Plantinga, nor Alston subscribe to the idea that multiple worldviews are substantially compatible.

Table 1 shows how the four philosophers of religion examined in this study compare with regard to the four factors which underpin a response to the epistemological challenge of religious diversity. As might be expected for a tabular summary, the representation is only approximate.

\begin{tabular}{|l|c|c|c|c|}
\hline Name & $\begin{array}{c}\text { Epistemic } \\
\text { Obligations }\end{array}$ & $\begin{array}{c}\text { Religious } \\
\text { Ambiguity }\end{array}$ & $\begin{array}{c}\text { Epistemic } \\
\text { Parity }\end{array}$ & $\begin{array}{c}\text { Religious } \\
\text { Incompatibility }\end{array}$ \\
\hline Swinburne & $\begin{array}{c}\text { Evidentialist } \\
\text { Internalist }\end{array}$ & No & No & Yes \\
\hline Plantinga & $\begin{array}{c}\text { Fideist } \\
\text { Externalist }\end{array}$ & No & No & Yes \\
\hline Alston & Externalist/Internalist & $\begin{array}{c}\text { Yes (for sake of } \\
\text { argument) }\end{array}$ & $\begin{array}{c}\text { Yes (for sake of } \\
\text { argument) }\end{array}$ & Yes \\
\hline Hick & Internalist & Yes & Yes & No \\
\hline
\end{tabular}

Table 1. A summary of how the four philosophers discussed in this study relate to the four key factors which shape one's response to the challenge of religious diversity.

In closing, we should note that belief is not the only aspect of religion. Smart says that in some forms of religion ritual is more important than belief and that differences in rituals can be just as important as differences in truth-claims. This study does not deny Smart's view but I would suggest that differences in belief are more fundamental than differences in ritual. This is because belief gives rise to action (see Swinburne Faith and Reason 9-15). A person would not perform religious rituals if he did not believe that performing the rituals is a good thing to do. With this in mind I hope that this study has done something to clarify different philosophical approaches to dealing with the challenge of religious diversity while upholding the reasonableness of religious belief.

\section{WORKS CITED}

Abraham, William J. E., An Introduction to the Philosophy of Religion. Englewood Cliffs (New Jersey): Prentice-Hall, 1985.

Alston, William P., Perceiving God: The Epistemology of Religious Experience. Ithaca and London: Cornell University Press, 1991.

- - - 'Response to Hick', Faith and Philosophy, 14:3 (1997): 287-288.

Askew, Richard, 'On Fideism and Alvin Plantinga', International Journal for Philosophy of Religion, 23 (1988): 3-16. 
Bishop, John, Believing by Faith: An Essay in the Epistemology and Ethics of Religious Belief. New York: Oxford University Press, 2007.

Bovens, Luc, and Stephan Hartmann, Bayesian Epistemology. Oxford: Clarendon Press, 2003.

Byrne, Peter, 'The Philosophical Approach to Questions about Religious Diversity.' The Oxford Handbook of Religious Diversity. Ed. Meister, Chad. New York: Oxford University Press, 2011. 29-41.

Chandler, Jake, and Victoria S. Harrison eds. Probability in the Philosophy of Religion. New York: Oxford University Press, 2012.

Clark, Kelly James ed., Return to Reason: A Critique of Enlightenment Evidentialism and a Defense of Reason and Belief in God. Grand Rapids, MI: William B. Eerdmans Pub. Co., 1990.

Evans, C. Stephen, Faith Beyond Reason: A Kierkegaardian Account. Grand Rapids, MI: William B. Eerdmans Pub. Co., 1998.

Greco, John, 'Reformed Epistemology.' The Routledge Companion to Philosophy of Religion. Eds. Meister, Chad and Paul Copan. London: Routledge, 2007. 629639.

Hick, John, 'The Epistemological Challenge of Religious Pluralism', Faith and Philosophy, 14:3 (1997): 277-286.

- - An Interpretation of Religion: Human Responses to the Transcendent. Houndmills (Hants.) and New York (NY): Palgrave Macmillan, 2004. (Originally published 1989.)

Hoitenga, Dewey, From Plato to Plantinga: An Introduction to Reformed Epistemology. Albany: State University of New York Press, 1991.

Jeffreys, Derek, 'How "Reformed" is Reformed Epistemology? Alvin Plantinga and Calvin's "Sensus Divinitatis"', Religious Studies, 33:4 (1997): 419-431.

King, Nathan, 'Religious Diversity and its Challenges to Religious Belief', Philosophy Compass, 3:4 (2008): 830-853.

Legenhausen, Muhammad, 'A Muslim's Non-Reductive Religious Pluralism: Religious Pluralism and the Pursuit of Peace.' Islam and Global Dialogue. Ed. Boase, Roger. Aldershot: Ashgate, 2005. 51-73. (An expanded version of this paper can be found at <http://www.uibk.ac.at/theol/leseraum/texte/626.html>, accessed 1 April 2012.)

Morton, Adam, A Guide Through the Theory of Knowledge. Malden, Oxford, Victoria, and Berlin: Blackwell, 2003.

Penelhum, Terence, God and Skepticism: A Study in Skepticism and Fideism. Dordrecht: D.Reidel, 1983.

Plantinga, Alvin, 'Reason and Belief in God.' Faith and Rationality: Reason and Belief in God. Eds. Plantinga, Alvin and Nicholas Wolterstorff. Notre Dame: University of Notre Dame Press, 1983. 16-93.

- - Warrant and Proper Function. New York; Oxford: Oxford University Press, 1993.

- - Warranted Christian Belief. Oxford and New York: Oxford University Press, 2000.

Race, Alan, Christians and Religious Pluralism: Patterns in the Christian Theology of Religions. London: SCM Press, 1983.

Schmidt-Leukel, Perry. 'Exclusivism, Inclusivism, Pluralism: The Tripolar Typology Clarified and Reaffirmed.' Myth of Religious Superiority. Maryknoll, NY: Orbis, 2005. 
Smart, Ninian. 'Truth and Religions.' Contemporary Philosophy of Religion. Eds. Cahn, Steven M. and David Shatz. New York: Oxford University Press, 1982. 291-300.

Swinburne, Richard. The Christian God. New York: Oxford University Press, 1994.

- - - 'Christianity and the Discourse of the World Religions: The Contribution of Philosophical Theology.' Philosophy Bridging the World Religions. Ed. Koslowski, Peter. Dordrecht: Kluwer Academic, 2003.

- - The Coherence of Theism. Oxford: Oxford University Press, 1977. (Revised 1993.)

- - Epistemic Justification. Oxford: Clarendon Press, 2001.

- - - The Evolution of the Soul. Oxford: Clarendon Press, 1986. (Revised 1997.)

- - - The Existence of God. Oxford: Clarendon Press, 2004. (Originally published 1979, revised 1991.)

- - - Faith and Reason. Oxford: Clarendon Press, 2005. (Originally published 1981.)

- - 'Intellectual Autobiography.' Reason and the Christian Religion: Essays in Honour of Richard Swinburne. Ed. Padgett, Alan G. New York: Oxford University Press, 1994. 1-18. (Near identical version in Kelly James. Clark ed. Philosophers Who Believe: The Spiritual Journeys of 11 Leading Thinkers. Downers Grove: InterVarsity Press, 1994.)

- - Is There a God? New York: Oxford University Press, 2010. (Originally published 1996.)

- - - Providence and the Problem of Evil. New York: Oxford University Press, 1998.

- - - 'Response to My Commentators', Religious Studies, 38:3 (2002): 301-315.

- - - Responsibility and Atonement. New York: Oxford University Press, 1989.

- - - The Resurrection of God Incarnate. Oxford: Oxford University Press, 2003.

- - Revelation: From Metaphor to Analogy. New York: Oxford University Press, 2007. (Originally published 1992.)

- - - Was Jesus God? Oxford: Oxford University Press, 2008.

Wolterstorff, Nicholas. 'Reformed Epistemology.' Philosophy of Religion in the 21st Century. Eds. Phillips, D. Z. and T. Tessin. Basingstoke: Palgrave Macmillan, 2001. 33-63. (Reprinted in Wolterstorff, Nicholas and Terence Cuneo eds., Practices of Belief: Selected Essays. Vol. 2, Cambridge \& New York: Cambridge University Press, 2009.) 
1 Some of these volumes have been revised and re-issued. Full details may be found in the bibliography. The tetralogy has been supported by some further books. Swinburne ('Intellectual Autobiography' 15) describes his The Evolution of the Soul as a 'prolegomenon' to his tetralogy; Epistemic Justification is described as a general epistemological appendix to the tetralogy, and The Resurrection of God Incarnate is described as a historical appendix (Swinburne 'Response to My Commentators' 313). See Supplement 1.

${ }^{2}$ Swinburne calls such a belief a 'rational ${ }_{5}$ ' belief (Faith and Reason 70-71).

${ }^{3}$ Bayesian epistemologists believe that the relationship between a hypothesis (h), evidence (e), and background evidence $(\mathrm{k})$ - also called background knowledge - is described by Bayes' theorem, which is a theorem that can be derived from axioms of probability calculus. One expression of the theorem suggests that the probability any given hypothesis is true given both specific evidence and background evidence is equal to the product of the explanatory power of the hypothesis and the prior probability of the hypothesis. It follows that Swinburne's assertions regarding what the true religion can be expected to be like is another feature in his approach to religious enquiry that receives support from bayesian epistemology. This is because the hypothesis that any given religion is true is, in part, dependent on the prior probability of it being (or, expectation that it is) true. For more information on bayesian epistemology see Bovens and Hartmann. Also see Chandler and Harrison.

${ }^{4}$ To understand what I am calling the 'negative aspect' of Plantinga's Christian apologetic one would have to be familiar with the justified true belief account of knowledge, Gettier counterexamples to this, and internalist and externalist accounts of epistemic justification. For an easy introduction to contemporary epistemology see Morton. The negative aspect of Plantinga's Christian apologetic also involves criticism of objections to Christianity which claim that it is unjustified (rather than plain false). Plantinga's claim is that the low standard of justification involved in these objections is the cause of their weakness (Warranted Christian Belief viii).

${ }^{5}$ Although Plantinga in fact argues that the best way to understand the notion of design plan is within a theistic metaphysical framework. As such, Plantinga sees his notion of warrant as a step in a version of Aquinas' fifth argument for the existence of God (Warrant and Proper Function 214).

${ }^{6}$ Sensus divinitatis is Latin for 'sense of divinity'.

${ }^{7}$ Thomas Aquinas (c.1225-1274) and John Calvin (1509-1564) were two Christian theologians who had differing theological views, particularly with regard to the role of the Church in salvation. According to Plantinga, both Aquinas and Calvin agree that there is a natural knowledge of God in human beings. Plantinga (Warranted Christian Belief 170) says that 'anything on which Calvin and Aquinas are in accord is something to which we had better pay careful attention.' But as Maria Rosa Antognazza points out in conversation, Aquinas has in fact argued against the existence of God being self-evident; see his Summa Theolagiae, la, qu. 1, art. 1-2. Care should be taken when comparing Aquinas and Plantinga on this point for they use 'self-evident' in different ways. According to Plantinga being self-evident is to be necessarily true and undeniable (Warranted Christian Belief 260-261) and is different to being properly basic. Nevertheless, it seems that Aquinas does not in fact support Plantinga's views on the sensus divinitatis. Similarly, Plantinga's reading of Calvin has also been called into question. See, for example, Jeffreys.

${ }^{8}$ This movement argues for a viewpoint on faith and rationality inspired by the Reformed tradition of Christianity. The major figures of this movement are William Alston, Alvin Plantinga, and Nicolas Wolterstorff. See Greco, Hoitenga, Wolterstorff.

${ }^{9}$ Plantinga ('Reason and Belief in God' 87-91) defends himself against the charge of being a fideist, a term which can be used by philosophers in a pejorative way given that it can imply a rejection of reason. But my understanding of 'fideism' here is very broad and used mainly for the want of a suitably religious term for 'anti-evidentialsim'. Besides, I am not alleging that Plantinga is himself a fideist, only that his defence of Christian beliefs does resemble a form of fideism even if not an extreme form. Askew (14) concurs with this assessment while defending Plantinga from Penhelum's (146-158) charge of fideism. Also see Kelly James Clark's (154-157) defence of Plantinga from not only Penelhum but also Abraham (87-97). For other broad characterisations of fideism similar to mine see (Bishop x, Evans 8-9).

${ }^{10}$ William Shakespeare, As You Like It, Act 2, scene 7.

${ }^{11}$ William Shakespeare, The Merry Wives of Windsor, Act 2, scene 2. 